PRZEGLĄDY - POLEMIKI - MATERIAŁY

Kwartalnik Historyczny Rocznik CXXI, 2014, 3

PL ISSN 0023-5903

BOGDAN WACHOWIAK

Poznań

\title{
UWAGI DO ARTYKUŁU RECENZYJNEGO JERZEGO DYGDAŁY DZIEJE FRYDERYCJAŃSKICH PRUS W XVIII W., CZYLI O WYŻSZOŚCI ABSOLUTYZMU NAD SZLACHECKĄ WOLNOŚCIĄ*
}

Jakkolwiek odnotowany w tytule problem roli systemu absolutnego i szlacheckiej wolności, jak wyjaśnia oznaczony gwiazdką odnośnik, został podjęty na marginesie tomu drugiego Historii Prus. Narodziny - MocarstwowośćObumieranie (pod red. Bogdana Wachowiaka, t. 2: Prusy w okresie monarchii absolutnej (1701-1806), opracowali [co nie zostało odnotowane!]: Zygmunt Szultka, Andrzej Kamieński, Grzegorz Kucharczyk, Bogdan Wachowiak, Poznań 2010, Wydawnictwo Poznańskie, ss. 1015), to jednak w rzeczywistości roli absolutyzmu Jerzy Dygdała poświęcił w swej opinii tylko jedną stronę, natomiast 94\% tekstu (17 na 18 stron) dotyczy odnotowanego wyżej tomu opracowania. Wynika stąd, że wyeksponowana w tytule artykułu recenzyjnego kwestia, mogąca - jak ujął to sam Autor - nasunąć się czytelnikowi (s.591), posłużyła głównie do nadania publikowanemu tekstowi neutralnie brzmiącego tytułu. Rzecz jednak w tym, że nie odzwierciedla on w pełni treści artykułu.Jego przedmiotem jest bowiem przede wszystkim krytyczna ocena tomu drugiego Historii Prus, zwłaszcza zaś łączonych zwykle $z$ funkcją redaktora kwestii metodologii i konstrukcji wykładu. Tych spraw dotyczyć będą też głównie poniższe uwagi wyjaśniające do ocen i sposobu ich formułowania przez Recenzenta. Dodam jednocześnie, że przyjęta formuła artykułu recenzyjnego, i to pod zakamuflowanym tytułem, ma również inny aspekt. Przyzwoliła bowiem na niedopełnienie w pełni wszystkich wymogów klasycznej recenzji, w której oprócz krytyki błędów, braków i niedociągnięć winny być, jak sądzę, ukazane także - naturalnie jeżeli takie można stwierdzić - podstawowe rezultaty oraz strony pozytywne

\footnotetext{
* Opublikowany w: KH 120, 2013, 3, s. 575-593.
} 
opracowania, w tym zwłaszcza badawczo-poznawcze, i to nie tylko na końcu tekstu w ogólnikowej i zdawkowej formie (iż oceniana praca stanowi „znaczące osiągnięcie naukowe” - s.592 - zespołu, czy środowiska historycznego), zwłaszcza że - jak sądzę - wniosek taki nie wynika w sposób oczywisty z tenoru wywodów Recenzenta.

Pierwszą kwestią, jaką w niniejszych uwagach wyjaśniających do wywodów Jerzego Dygdały w sprawie opracowania dziejów Prus w okresie monarchii absolutnej chciałbym podnieść, jest w moim przekonaniu fundamentalna sprawa genezy powstania, celów i zadań poznawczych oraz konstrukcji tego opracowania. Recenzent, podnosząc temat na początku artykułu, widzi go w skrócie następująco: po II wojnie światowej w ramach zadań postawionych przez ówczesnych decydentów znalazło się opracowanie przy zastosowaniu marksistowskiej metodologii syntezy Historii Polski, obejmującej także Pomorze i Śląsk, których odwieczne związki z Polską Piastowską należało udowodnić. W rezultacie tej dyrektywy powstały kilkutomowe syntezy dziejów obu regionów, a podjęte w połowie lat osiemdziesiątych XX w. w środowisku poznańskim prace nad pełną historią państwa brandenbursko-pruskiego miały wspomniane publikacje na temat dziejów Pomorza i Śląska „niejako uzupełniać”. Opracowanie to miało, zdaniem Recenzenta, ,nawiązywać w zakresie metodologicznym (i konstrukcyjnym) do wypracowanych już [- - ] zasad tworzenia wielkich, często drobiazgowych syntez" (s. 575-576). Pierwszą zrealizowaną częścią tego przedsięwzięcia był wydany w 2001 r. tom pierwszy Historii Prus zatytułowany Dzieje Brandenburgii-Prus na progu czasów nowożytnych (1500-1701), z tym, że redaktor i autorzy tomu - wyżej podpisany i Andrzej Kamieński - również nie zostali w recenzji odnotowani.

Na marginesie powyższych częściowo prawdziwych konstatacji Jerzego Dygdały, ale generalnie w odniesienie do historii genezy Historii Prus, kreślących mylący i poważnie odbiegający od faktycznego biegu rzeczy obraz sytuacji, należy przypomnieć znany fakt, że potrzebę opracowania dziejów Prus historycy polscy dostrzegali już przed II wojną światową. Początkowo chodziło wprawdzie przede wszystkim o Prusy Wschodnie, ale problematyka dziejów państwa pruskiego, chociaż ujmowana przede wszystkim w punktu widzenia polskiego, została ponownie podjęta także przez historiografię polską po $1945 \mathrm{r}$. i była ważnym przedmiotem w dialogu toczącym się nie tylko w ramach Komisji Podręcznikowej z badaczami niemieckimi, zwłaszcza z ówczesnej Republiki Federalnej Niemiec. Istotne znaczeniu dla postępu w badaniach przeszłości monarchii Hohenzollernów miała także międzynarodowa sesja prusoznawcza w czerwcu 1970 r., której materiały wydane zostały pod red. Gerarda Labudy jako Węzłowe problemy dziejów Prus XVII-XX wieku (Poznań 1971). 
Na ukazanie się pierwszego całościowego opracowania dziejów Prus trzeba było jednak poczekać do połowy lat osiemdziesiątych XX w. Pionierską próbę takiego ujęcia, pozytywnie ocenioną w kraju i za granicą, wydaną także w wersji niemieckojęzycznej, przedstawił Stanisław Salmonowicz (Prusy. Dzieje państwa i społeczeństwa, wyd. 1, Poznań 1987), także autor nieco wcześniej wydanej biografii Fryderyka II (Wrocław 1981). Pomimo dużej zbieżności dat ukazania się dziejów Prus pióra S. Salmonowicza i początków prac nad rozszerzonym kilkutomowym opracowaniem całości dziejów państwa Hohenzollernów, nie były to bynajmniej przedsięwzięcia konkurencyjne. Zarówno profesor Stanisław Salmonowicz, jak i autor tych Uwag - inicjator i kierunkujący pracami poprzedzającymi opracowanie rozszerzonej wersji Historii Prus - byliśmy pracownikami Instytutu Historii PAN oraz uczestniczyliśmy i współpracowaliśmy w badaniach dziejów Prus - piszący te słowa m.in. jako recenzent wydawniczy wspomnianej Historii Prus Stanisława Salmonowicza, natomiast badacz ten jako potencjalny autor tomu drugiego (z czego jednak ostatecznie sam zrezygnowat) aktywnie uczestniczył w prusoznawczych konferencjach i pracach przygotowawczych nad napisaniem pełnej syntezy, jakie były prowadzone przez szereg lat $\mathrm{z}$ udziałem badaczy z obu ówczesnych państw niemieckich. Ich celem było nie tylko podsumowywanie aktualnego stanu badań Prus, ustalanie potrzeb i problematyki badawczej, ale także sporządzenie konspektu całości opracowania od średniowiecza po rok 1947. Kilkuletnie wstępne prace nie toczyły się w tajemnicy, gdyż ich rezultaty i etapy znajdowały odbicie w publikacji materiałów z ważniejszych odbytych sesji i narad (por. zwłaszcza Dzieje Brandenburgii i Prus w historiografii, pod red. B. Wachowiaka, Warszawa-Poznań 1989 oraz materiały sesyjne w „Polnische Weststudien", t. 5, z.1,1986; t. 6, z. 2, 1987).

Edycje te i fakt kilkuletnich prac nad koncepcją i konspektem Historii Prus są zapewne znane Recenzentowi, który był już wtedy od kilku lat pracownikiem naukowym placówki toruńskiej Zakładu Historii Pomorza IH PAN, ale pomimo to nie uznał za stosowne o nich wspomnieć. Moge postawić jedynie pytanie: dlaczego? Jest ono tym bardziej zasadne, że tok prac wstępnych i wypracowane wówczas założenia metodyczne i metodologiczne, łącznie z oceną stanu badań, podstawową problematyką Prus oraz głównymi celami i problemami badawczymi zostały, jakkolwiek może zbyt skrótowo, przedstawione przez redaktora całości syntezy nie tylko w drugim, recenzowanym przez Jerzego Dygdałę tomie Historii Prus, ale także we wspomnianym już tomie pierwszym, inaugurującym całość opracowania. To, iż zabrakło nawet wzmianki o tym, że dotyczące powyższych kwestii wprowadzenia istnieją i co zawierają, należy uznać za istotne niedopełnienie podstawowego obowiązku recenzenta. 
Zignorowanie scharakteryzowanych nie tylko we „Wprowadzeniu” do tomu pierwszego, ale także do tomu drugiego, ocenianego przez Jerzego Dygdałę, faktycznych założeń oraz przyjętej metodologii opracowania całości dziejów Prus w ujęciu strukturalnym, uwzględniającym wszystkie dziedziny życia omawianego państwa od gospodarki, poprzez politykę, problematykę ustrojowo-prawną po demografię oraz tematykę kultury duchowej i materialnej ${ }^{1}$, jest tym bardziej zastanawiające, że opracowany w oparciu o podobne założenia, opublikowany w 2001 r. wspomniany tom pierwszy, obejmujący dzieje Brandenburgii-Prus w latach 1500-1701, został bardzo pozytywnie przyjęty przez wszystkich bez wyjątku jego recenzentów, i to nie tylko krajowych ale także, a może nawet przede wszystkim zagranicznych. Odnotować pragnę zwłaszcza wnikliwą, i podkreślającą walory nowatorskiego ujęcia początków państwa Hohenzollernów opinię Michaela G. Müllera. Badacz ten zauważył nie tylko wkład nowego ujęcia dziejów Prus do przezwyciężenia polonocentryzmu polskich badań, ale także programowe rozszerzenie ich spektrum, a także wysoki poziom opracowania, w wyniku czego miało ono istotne znaczenie dla pełniejszego poznania przeszłości nie tylko Prus i Niemiec, ale nawet całej Europy ${ }^{2}$. Warto także odnotować, że w ostatnim zdaniu swej rzeczowej i pozytywnej opinii na temat tomu pierwszego syntezy inny recenzent niemiecki Stefan Hartmann - podkreślił, że jest ona tak instruktywna dla niemieckich badań nad dziejami Prus, że postulował jej tłumaczenie na język niemiecki ${ }^{3}$, natomiast czołowy znawca problematyki polsko-niemieckich dziejów Klaus Zernack, dziękując za przesłany egzemplarz pierwszego tomu, stwierdził: „Gleichzeitig gratuliere ich Ihnen und Herrn Kollegen Kamienski zu diesem Werk, das unsere dt.-poln. Preußen-Diskusionen auf eine feste Basis stellt"4. Pozytywne oceny omawianego tomu opublikowali także badacze polscy: Maria Bogucka, Grzegorz Białuński i Józef Włodarski ${ }^{5}$, pisemnie wyraził je też Marian

${ }^{1}$ Instruktywne wydaje się w tym miejscu wskazanie na charakterystykę Metody strukturalnej w poznawaniu i przedstawianiu historii dziejów Gerarda Labudy opublikowaną w cz. 2 publikacji Rozwój metod dziejopisarskich od starożytności do współczesności, Poznań 2010, s. 89-154. Dodam, ze badacz ten w cz. 1 swego studium metod dziejopisarskich przedstawił także odrębnie Metodę materialistyczno-dialektyczną Karola Marksa i Fryderyka Engelsa (Poznań 2003, s. 111-178), znacznie różniącą się od metody strukturalnej.

${ }^{2}$ Recenzja w języku niemieckim opublikowana w: ZH 68, 2003, 2-3, s. 253-256.

3 "Jahrbuch für die Geschichte Mittel- und Ostdeutschlands", t. 48, 2002 [druk 2003], s. 338-340.

${ }^{4}$ Kartka wysłana do mnie 17 października $2001 \mathrm{r}$.

${ }^{5}$ Pierwsza recenzja w KH $(109,2002$, 3, s. 193-197), druga w „Komunikatach Mazursko-Warmińskich” (2003, nr 3 (241), s. 394-397), trzecia w „Studenckich Tekach 
Biskup $^{6}$ - uczestnik prac poprzedzających opracowanie Historii Prus i długoletni kierownik Zakładu Historii Pomorza IH PAN.

Pozytywne oceny tomu pierwszego nie przesądzają oczywiście o jakości opracowania tomu drugiego Historii Prus, będącego głównym przedmiotem recenzji i niniejszych uwag wyjaśniających. Zasadne wydaje się w związku z tym odnotowanie tego, czego w opinii Jerzego Dygdały nie znajdujemy, mianowicie że stanowi on kontynuację pierwszego tomu, napisanego $\mathrm{w}$ oparciu o te same założenia co tom drugi, dostosowane tylko, zwłaszcza w zakresie problematyki i celów badawczych, do zmienionych warunków zewnętrznych i wewnętrznych rozwoju państwa pruskiego. Te ostatnie wprowadziły bowiem istotne zmiany w hierarchii problemów, przed jakimi to państwo w XVIII w. stanęło i jakie miało do rozwiązania. $Z$ satysfakcją mogę stwierdzić, że również ten tom drugi, poświęcony dziejom Prus w latach 1701-1806, mimo swej złożonej i skomplikowanej problematyki badawczej oraz wielu innych czynników, ze stanem badań na czele, które utrudniły autorom i redaktorowi pełne i jednoznaczne rozwiązywanie problemów, został, generalnie biorąc, zdecydowanie pozytywnie oceniony przez czołowego polskiego znawcę epoki i dziejów Prus w okresie oświeconego absolutyzmu profesora Stanisława Salmonowicza ${ }^{7}$.

Jeżeli chodzi natomiast o oceny Jerzego Dygdały zawarte w jego artykule recenzyjnym na temat drugiego tomu Historii Prus, to są one zdecydowanie bardziej zróżnicowane i ocenom pozytywnym - jakie także znajdujemy - towarzyszą często opinie krytyczne, i to nie tylko w odniesieniu do scharakteryzowanej już sprawy metodologii i genezy tej publikacji. Ograniczając się do wybranych przykładów, odnotować pragnę, że podkreśleniu skrupulatnego wykorzystania literatury przedmiotu towarzyszy stwierdzenie stawiające pod znakiem zapytania celowość

Historycznych" Koła Naukowego Historyków Uniwersytetu Gdańskiego (R. 1, z. 1, 2002, s. 57-60).

${ }^{6}$ Prof. Marian Biskup w liście do mnie z 29 lipca 2001 r. napisał: „A więc stało się, czego należało się spodziewać: że polski historyk napisał istotny fragment dziejów Brandenburgii zmierzającej do «federacji» z Prusami Książęcymi i rozłożenia Rzeczpospolitej (ratalnie!). Napisał to w sposób bijący o głowę prusko-berlińskich historyków i pokazujący, jak trzeba dzisiaj pisać o sprawach brandenbursko-prusko-polskich. Nauczyliśmy się od niemieckich naukowców sporo, ale teraz sytuacja się zmieniła (odczuwałem to już od pewnego czasu przy Historii Zakonu Krzyżackiego w Prusach i Inflantach i przy historii Pomorza), tylko czy oni przyjmą to do wiadomości, czy wyciągną wnioski - ale to już będzie ich szkoda i cofanie się na stare pozycje (starzejące się...). Gratuluję szczerze I tomu i życzę rychłego zmontowania t. II i dotrwania do ostatniego - tylko nie zrażaj się trudnościami...".

7 S. Salmonowicz, o klasycznej monarchii pruskiej z lat 1701-1806, „Czasy Nowożytne”, t. 24, 2011, s. 233-247. 
umieszczenia w pracy napisanego przez autora niniejszych Uwag rozdziału zawierającego charakterystykę źródeł i opracowań, gdyż w opinii Recenzenta przypisy zostały nadmiernie rozbudowane i zawierają tytuły odnotowane także we wspomnianej charakterystyce. Autor artykułu, podkreślając bogactwo faktograficzne tomu, stwierdził też, że zamiast syntezy otrzymaliśmy „zbiór studiów niekiedy wręcz monograficznych” (s. 576). Ze swej strony pragnę skonstatować, że omówienie stanu badań to nie tylko wykaz cytowanej literatury i podstawy źródłowej dublowany następnie w przypisach, a szczegółowość wykładu opartego często na materiałach archiwalnych wynikała nie tylko z nadmiernej drobiazgowości autorów, ale przede wszystkim z niedostatków dotychczasowych badań. Strukturę wewnętrzną opracowania Jerzy Dygdała ocenił jako przejrzystą, napisaną przystępnym językiem, a wynikający z przyjętej periodyzacji podział na części uznał za trafny, jednak już konstrukcję tych części określił jako zagmatwaną i nieprzejrzystą, „by nie powiedzieć chaotyczną". Jednym z powodów tego chaosu były - zdaniem Recenzenta - niedostatki w charakterystyce i ukazaniu przez autorów roli władców pruskich. W jego opinii każda część opracowania powinna bowiem zaczynać się od przedstawienia sylwetek kolejnych królów pruskich, ich wykształcenia, kompetencji, koncepcji politycznych, zainteresowań itp. (s. 577), a w innym miejscu zamiast przyjętego układu terytorialnego przy prezentacji polityki pruskiej lat 1772-1786 zalecił wręcz zastosowanie prostej narracji chronologicznej (s. 582). Jako komentarz do tej propozycji warto zauważyć, że prezentacje dziejów Prus, których kośćcem był tok życia i działalności władców, znane są historykom, ale jak dotąd nie doprowadziły one do pełnego wyjaśnienia wszystkich zagadnień i aspektów dziejów pruskich, zwłaszcza niezwykle skomplikowanego wieku XVIII.

Pozostawiając właściwym adresatom, czyli współautorom tomu drugiego: Zygmuntowi Szultce, Andrzejowi Kamieńskiemu, Grzegorzowi Kucharczykowi i Dariuszowi Łukasiewiczowi do rozważenia dalsze uwagi sformułowane przez Jerzego Dygdałę w toku dość szczegółowej charakterystyki oraz omówień treści, walorów i uchybień ich tekstów, ze swej strony zauważyć pragnę, że sposób prezentowania zawartości i ocen w moim odczuciu cechuje nadmierna koncentracja na sposobie ujęcia konkretnych zagadnień traktowanych przede wszystkim jako wyodrębnione tematy, a nie jako fragmenty ogólniejszych procesów rozwojowych państwa pruskiego w XVIII w. Tymczasem nie ulega wątpliwości, że wspomniane stulecie trzeba zaliczyć do kluczowych w dziejach monarchii Hohenzollernów. Z niewielkiego państwa podległego w pełni lennej władzy zwierzchniej cesarza Prusy wyrosły w ciągu tego stulecia na mocarstwo odgrywające istotną rolę w koncercie państw europejskich. Wyjaśnienie, 
jak do tego doszło i przy zastosowaniu jakich środków, było podstawowym zadaniem zespołu autorskiego tomu. Zadaniem recenzenta winna być natomiast ocena, czy nakreślone w przedmowie cele i zadania udało się autorom tomu drugiego zrealizować oraz czy i w jakim zakresie przyczynili się oni do postępu w badaniach tego okresu dziejów Prus. Próba ukazania tej problematyki w całej złożoności oraz charakterystyki osiągniętych rezultatów badawczych została podjęta przez redaktora tego tomu w zamykających go Głównych liniach rozwoju Prus w okresie monarchii absolutnej. Podsumowanie to określone w recenzji w nawiasie jako „w jakiejś mierze streszczenie" zostało wprawdzie przez Jerzego Dygdałę odnotowane, ale poza ogólnym stwierdzeniem, iż chodzi o prezentację głównych wątków syntezy, zabrakło szczegółowszego omówienia treści. Autor artykułu recenzyjnego zakwestionował jedynie zawarty w zakończeniu fragment dotyczący roli Polski i jej miejsca w dziejach Prus, w szczególności zaś tezy, iż „włączenie w skład państwa pruskiego ziem polskich [- - ] stało się przyczyną trudności z unifikacją tego organizmu państwowego w XIX w." i jednym z istotnych powodów upadku Prus. W tym kontekście pragnę zauważyć, że jedną z cech ujemnych historiografii niemieckiej było niedostrzeganie miejsca i roli Polski w dziejach Prus, znaczenia rozbiorów nie wyłączając. Te ostatnie były, a niekiedy są nadal odnotowywane z reguły z pominięciem następstw, jakie niosły ze sobą dla Prus i Rzeczypospolitej, oraz tylko jako wydarzenie, bynajmniej nie wyjątkowe w Europie. Przeciwstawiając się tej germanocentrycznej optyce, w syntezie szczególnie wyraźnie odnotowano i podkreślono (s. 586/587) rozrost terytorialny Prus kosztem ziem polskich i z Polską związanych, zaznaczając, że chodziło początkowo (przed 1806 r.) o 55\% obszaru całych Prus (44\% stanowiły ziemie włączone w rezultacie rozbiorów, $11 \%$ to obszar Śląska). Nie ulega też wątpliwości, że rozbiory Polski przyniosły państwu Hohenzollernów nie tylko korzyści, ale i stworzyły Prusom i następnie Rzeszy Niemieckiej także różnego rodzaju trudne do przezwyciężenia problemy. W syntezie reprezentowany jest pogląd, że problem Polski w dziejach Prus swymi początkami sięgał drugiej połowy XVIII w. i jego powstanie wiązało się ściśle z uczestnictwem Hohenzollernów w rozbiorach Polski. Jest dla autora tych Uwag także rzeczą całkowicie niezrozumiałą, dlaczego zakończenie sumujące rezultaty badawcze tomu drugiego i kreślące główne linie rozwoju Prus w XVIII w. zostało w swej wersji polskojęzycznej uznane za zbędne w recenzowanym tomie. Jerzy Dygdała uznał za celowe i pożyteczne opublikowanie jedynie niemieckojęzycznej wersji zakończenia. Nasuwa się też pytanie, czy za zignorowaniem treści Wprowadzenia oraz krytyką ujęcia opracowania, a ponadto zakwalifikowaniem kilku wspomnianych w niniejszych uwagach fragmentów tekstu 
jako zbędnych kryje się tylko troska o zmniejszenie objętości opracowania przynoszące oszczędność papieru, czy też próba dewaluacji walorów naukowo-poznawczych wkładu autorskiego i koncepcyjnego redaktora dyskutowanego tomu syntezy.

Poznań, 2 stycznia 2014 r. 